\title{
Pheochromocytoma combined with unusual form of Cushing's syndrome and pituitary microadenoma
}

\author{
W K A Khalil ${ }^{1}$, J Vadasz ${ }^{4}$, E Rigo ${ }^{1}$, L Kardos ${ }^{2}$, L Tiszlavicz ${ }^{3}$ and L Gaspar ${ }^{1}$ \\ ${ }^{1}$ Endocrine Unit, ${ }^{2}$ Department of Radiology and ${ }^{3}$ Department of Pathology, Albert Szent-Györgyi Medical University, Szeged, Hungary and \\ ${ }^{4}$ Geza Hetenyi County Hospital, Szolnok, Hungary
}

(Correspondence should be addressed to L Gaspar, Endocrine Unit, Albert Szent-Györgyi Medical University, Szeged, Hungary, P O Box 427, H-6701, Korányi fasor 8, Hungary)

Issa and coworkers have reported an interesting case of Cushing's disease with undetectable urinary free cortisol in your Journal (1). We recently diagnosed a patient with pheochromocytoma and with normal levels of serum cortisol and adrenocorticotropin (ACTH) lacking diurnal rhythm causing an unusual form of Cushing's syndrome.

Hypercortisolism in patients with tumors of the autonomic nervous system has been reported previously. Luton et al. reviewed cases with pheochromocytoma and hypercortisolism due to adrenal tumors (2). Other combinations include the production of steroid hormones by a tumor of the autonomic nervous system, concomitant adreno-cortical and -medullary tumors, ectopic production of corticotropin releasing factor (CRF), and multiple endocrine neoplasia $(3,4)$. Hypercortisolisms have been reported to be connected with paragangliomas, with either an increased plasma ACTH level or identifiable corticotropin in the tumor.

Our patient, a 44-year-old woman, exhibited moderate obesity, hypertension and psychiatric problems (depression). Her vital signs were: blood pressure (BP) 240/150-160/90 $\mathrm{mmHg}$, pulse rate 100-90/ min eurhythmic. Laboratory data showed blood sugar $5.0 \mathrm{mmol} / \mathrm{l}$, and cholesterol $7.1 \mathrm{mmol} / \mathrm{l}$. Serum cortisol levels were normal, but without a diurnal rhythm $(02.00 \mathrm{~h}, 364 \mathrm{nmol} / \mathrm{l}$; $08.00 \mathrm{~h}, 447 \mathrm{nmol} / \mathrm{l})$. Serum ACTH was in the normal range $(13.43 \mathrm{pmol} / \mathrm{l})$. During suppression tests, $2 \mathrm{mg}$ and $8 \mathrm{mg}$ dexamethasone failed to reduce serum cortisol levels. The 24-h urinary epinephrine and norepinephrine levels, as measured by fluorimetry, were 0.106-0.108 and 1.070$0.703 \mu \mathrm{mol}$ respectively. These elevated values were not suppressed by clonidine. All other hormones measured were in the normal ranges. NMR investigation of the sella turcica revealed a pituitary microadenoma ( $4 \mathrm{~mm}$ in diameter) on the right side of the adenohypophysis.

On abdominal CT, a $2.5 \mathrm{~cm}$ mass was seen in the region of the left adrenal. After dibenilyne pretreatment, the left adrenal was removed.

After removal of the left adrenal, the patient displayed clinical and laboratory signs of hypoadrenalism and was treated with glucocorticoid substitutive therapy.
Urinary catecholamine levels became normal. Histological examination revealed a typical pheochromocytoma exhibiting a pseudoglandular pattern of growth; the tumor cells were aligned around spaces. Part of the removed tissue displayed a nodule of cortical nodular hyperplasia with both clear and compact cells. ACTH immunohistochemistry revealed no positive cells in the tumor tissue; however, HPLC analysis demonstrated ACTH and various forms of $\alpha$-melanocyte-stimulating hormone (MSH)-immunoreactive material in the tumor tissue.

Besides pheochromocytomas, extra-adrenal paragangliomas have been associated with Cushing's syndrome. Immunologic assays of tumor tissues have identified the usual cause as ectopic ACTH production $(5,6)$. In the present case, the serum ACTH level was normal, suggesting that the pituitary microadenoma might not play a major role in the Cushing's phenomena of this patient. Meloni et al. also reported a patient with a benign adrenomedullary tumor associated with bilateral adrenal hyperplasia and Cushing's syndrome (7). Our case involved a unilateral pheochromocytoma containing $\alpha$-MSH and ACTH-immunoreactive material, and a nodular hyperplasia of the adrenal cortex ipsilaterally. Ito et al. detected $\alpha$-MSH immunoreactivity in a human pheochromocytoma (8). At least six different molecular forms of $\alpha$-MSH can be found in human pheochromocytomas (J Gardi, personal communication). It can be speculated that ACTH and possibly other products of pro-opiomelanocortin (via the paracrine route) may trigger catecholamine and cortisol secretion from the adrenal medulla and cortex respectively (9). However, this needs to be investigated further.

\section{References}

1 Issa BG, Page MD, Read G, John R, Douglas-Jones A \& Scanlon MF. Undetectable urinary free cortisol concentrations in a case of Cushing's disease. European Journal of Endocrinology 1999140 148-151.

2 Luton JP, Thieblot PH \& Bricaire H. Association syndrome de Cushing-pheochromocytome. Nouvelle Presse-Medicale 19776 4053-4057. 
3 Forman BH, Marban E, Kayne RD, Passarelli NM, Bobrow SN, Livolsi VA, Merino M, Minor M \& Farber LR. Ectopic ACTH syndrome due to pheochromocytoma: case report and review of the literature. Yale Journal of Biology and Medicine 197952 181-189.

4 Crowell WT, Grizzle WE \& Siegel AL. Functional carotid paragangliomas: biochemical, ultrastructural, and histochemical correlation with clinical symptoms. Archives of Pathology and Laboratory Medicine 1982106 599-603.

5 Ball SG, Davison JM, Burt AD, McNicol AM \& Baylis PH. Cushing's syndrome secondary to ectopic ACTH secretion from a primary ovarian carcinoma. Clinical Endocrinology 199645 775-778.

6 Schteingart DE, Conn JW, Orth DN, Harrison TS, Fox JE \& Bookstein JJ. Secretion of ACTH and $\alpha$-MSH by an adrenal medullary paraganglioma. Journal of Clinical Endocrinology and Metabolism 197234 676-683.
7 Meloni CR, Tucci J, Canary JJ \& Kyle LH. Cushing's syndrome due to bilateral adrenocortical hyperplasia caused by a benign adrenal medullary tumor. Journal of Clinical Endocrinology and Metabolism $1966261192-1200$.

8 Ito S, Iwanaga T, Yamada Y, Suzuky T, Sudo N, Momotsu T \& Shibata A. Immunohistological demonstration of ACTH-like immunoreactivity in the foetal adrenal medulla in the 23rd week of gestation. Acta Endocrinologica $198197412-418$.

9 de Keyzer Y, Rousseau Merck MF, Luton JP, Girard F, Kahn A \& Bertagna X. Pro-opiomelanocortin gene expression in human phaeochromocytomas. Journal of Molecular Endocrinology 19892 175-181.

Received 21 July 1999

Accepted 18 August 1999 